\section{References}

1. Watkins, P. J.: Diabetes mellitus: A new look at diagnostic criteria (Letter to the Editor). Diabetologia 17, 127-128 (1979)

2. Tchobroutsky, G.: Relation of diabetic control to development of microvascular complications. Diabetologia 15, 143-152 (1978)

3. Jarrett, P. J., Keen, H., Fuller, J. H., McCartney, M.: Worsening to diabetes in men with impaired glucose tolerance ("borderline diabetes"). Diabetologia 16, 25-30 (1979)
4. FitzGerald, M. G., Keen, H.: Diagnostic classification of diabetes. Br. Med. J. 1964 I, 1568

Dr. A. G. Cudworth

Department of Medicine

St. Bartholomew's Hospital Medical College

West Smithfield

London EC1A 7BE

England

\title{
Catecholamines and Diabetes Mellitus
}

\section{Dear Sir,}

The recent survey of Dr. Christensen (1979) on catcholamines and diabetes mellitus covers most of the present knowledge in this field of research. It appears necessary, however, to stress the potential importance of one particular aspect of catecholamine action which has been neglected by the author.

Only recently has it been recognized that chronic elevated or decreased levels of hormones tend to be associated with changes of hormone responsiveness of target tissues. These changes include hormone refractoriness or changes in the qualitative pattern of effects of a number of hormones, including catecholamines [4]. In vitro experiments with human adipose tissue showed that the lipolytic effects of the naturally occurring catecholamines are impaired in untreated juvenile diabetics $[1,2]$. This impairment was due to an altered balance of $\alpha$-and $\beta$-adrenergic responsiveness with increased with increased receptivity for both components of catecholamine action. The conclusion of Dr. Christensen that elevated catecholamine levels in untreated insulin-deficient diabetics serve to compensate for volume depletion at the expense of an aggravated metabolic disturbance, is therefore, an overextrapolation. At least in adipose tissue, metabolic disturbance by elevated catecholamine levels is likely to be prevented via an adaptive change of hormone sensitivity at the level of the target tissue.

It is of special interest to clarify the mechanism of this type of adaptive change or hormone responsiveness. This involves questions concerning the modulation of the response to drugs by disease and is pertinent to the actual discussion about the use of $\beta$ blocking agents in diabetics. This phenomenon, for instance, may contribute to the fact that carbohy- drate tolerance can improve and insulin secretion can increase when mild diabetics are changed from a non-selective $\beta$-blocking drug to metroprolol, where as longterm treatment with either propranolol or metroprolol failed to change carbohydrate tolerance in non-diabetic subjects [5]. In addition, the increased responsiveness towards $\beta_{2}$-selective agonists lacking the inhibitory alpha-adrenergic component of action, which was observed by Fredholm et al. [3] in diabetic women, is perhaps due to this type of adaptive change of hormone responsiveness at the level or target tissues.

Dr. Horst Kather Dr. Bernd Simon

\section{References}

1. Arner, P., Óstman, J.: Abnormalities in the adrenergic control and the rate of lipolysis in isolated human subcutaneous adipose tissue in diabetes mellitus. Diabetologia 12, 593-599 (1976)

2. Arner, P., Engfeldt, P., Östman, J.: Relationship between lipolysis, cyclic AMP, and fat-cell size in human adipose tissue during fasting and in diabetes mellitus. Metabolism 28, 198-209 (1979)

3. Fredholm, B. B., Lunell, N. O., Persson, B., Wager, J.: Actions of salbutamol in late pregnancy: Plasma cyclic AMP, insulin and C-peptide, carbohydrate and lipid metabolites in diabetic and non-diabetic women. Diabetologia 14, 235-242 (1978)

4. Tell, G.P., Haour, F., Saez, J.M.: Hormonal regulation of membrane receptors and cell responsiveness: A review. Metabolism 27, 1566-1592 (1978)

5. Waal-Manning, H. J.: Metabolic effects of $\beta$-adrenoceptor blockers. Drugs 11 (Suppl.), 121-126 (1978)

Dr. H. Kather, Dr. B. Simon

Klinisches Institut für Herzinfarktforschung

Medizinische Universitätsklinik

Bergheimer Straße 58

D-6900 Heidelberg, Federal Republic of Germany 